\title{
Development of Bahiagrass Fertilization Recommendations: 1990-20051
}

\section{E.A. Hanlon, Rao Mylavarapu, I.V. Ezenwa² \\ Introduction and Intent}

In 1990, Bahiagrass recommendations for both liming and fertilization were reviewed by an ad hoc committee including faculty members from the Soil $\&$ Water Science and the Agronomy Departments, and discussions with selected state and county extension faculty members. In 1994, the Bahiagrass Fertilization Working Group was formed to complete a more formal review of Bahiagrass liming and fertilization recommendations produced by the Extension Soil Testing Laboratory (ESTL). The intent of the Working Group was to review the literature and based on best professional judgment devise appropriate liming and fertilization recommendations to be used by the ESTL and in statewide extension programs. The Working Group completed its task in 1996 when the white paper produced by the Working Group was approved by UF/IFAS administration through the Plant Nutrient Oversight Committee, a representative committee from all levels of UF/IFAS.

In 2000, as an activity of the Suwannee River Partnership, the Florida Department of Agriculture and Consumer Service (FDACS) led an effort to develop Interim Measures for Nitrogen for Hay Production. With UF/IFAS as a crucial member, the Suwannee Fertilizer Work Group (SFWG), a technical subcommittee, was constituted and charged with the responsibility of evaluating the nutrient management practices in the Suwannee basin. Through a letter in March 2000, the FDACS asked the SFWG to "begin discussions concerning the implementation of improved nutrient practices in the SRB [Suwannee River Basin] for forage crops as they represent largest acreage in the basin." The scope of this responsibility was described by the FDACS through the following working definition (Florida Legislature, 2001):

"Best Management Practices mean[s] practices or combinations of practices determined by research or field testing in representative sites to be the most effective and practicable methods of fertilization designed to meet nitrate groundwater quality standards, including economic and technological considerations."

1. This document is SL-237, one of a series of the Soil and Water Science Department, Florida Cooperative Extension Service, Institute of Food and Agricultural Sciences, University of Florida. Original publication date January 2006. Revised March 2006. Visit the EDIS Web Site at http://edis.ifas.ufl.edu.

2. E. A. Hanlon, professor, Soil and Water Science Department, Southwest Florida Research and Education Center--Immokalee, FL; R. Mylavarapu, associate professor, Soil and Water Science Department; I. V. Ezenwa, assistant scientist, Southwest Florida Research and Education Center--Immokalee, FL; Florida Cooperative Extension Service, Institute of Food and Agricultural Sciences, University of Florida, Gainesville, FL 32611. 
Soil-test fertilization recommendations from UF/IFAS have been developed for optimum crop production based on crop nutrient requirements. While being aware of environmental issues, actual assessment of environmental impacts was not an objective of state soil-testing programs in the past. Economic and technological considerations, as defined by FDACS above, are only recent additions to research activities that will aid in refining soil-test-based nutrient recommendations.

Calibrated soil testing that includes documented environmental outcomes and produces a commercially viable crop is the goal set by all parties in the SFWG. Nutrient-management research that also considers environmental aspects of fertilization has begun. In this interim period, FDACS has defined the documented recommendations described in this document as "Interim Measures" (FDACS, 2005), a pre-BMP stage.

"Interim Measures mean primarily horticultural practices consistent with the fertilizer recommendations published by the University of Florida or the Florida A\&M University or modified by the FDACS, to reflect public input." (FDACS, 2005)

In response to the above goal in 2003, IFAS researchers and extension specialists developed new footnotes, modified some of the previous footnotes, and created a new crop code for Hay crops to enable processing of the soil samples and reports through the ESTL (Mylavarapu, 2003).

In 2004, the Forage Fertilization Working Group was formed and charged with the review of all UF/IFAS fertilization and liming recommendations for grass and forage production throughout the state. As this Working Group proceeds through UF/IFAS recommendations, Bahiagrass recommendations will be reviewed once again. This document describes the history of Bahiagrass recommendations from 1990 through 2003, and summarizes the work of the various work groups and committees mentioned above. The results of these efforts have been described in EDIS document SL129 (Kidder et al. 2002). This document provides a history of past Bahiagrass recommendation decision-making, and should aid the Forage Fertilization Working Group with future recommendation development. Ranchers, forage producers, and other interested parties may also use the information in this document to understand the basis for UF/IFAS Bahiagrass liming and fertilization recommendations.

\section{Bahiagrass Fertilization Recommendations established in 1990}

\section{Target Soil pH}

The target soil $\mathrm{pH}$ for Bahiagrass production was 5.5. A lime requirement test was completed whenever the observed soil $\mathrm{pH}$ was 5.3 or less. A lime requirement recommendation was made to the nearest 0.5 ton/acre. These practices fit the literature available in 1990 and were implemented by the ESTL in that year.

\section{Phosphorus and Potassium}

The agronomic interpretation scale for both $\mathrm{P}$ and $\mathrm{K}$ (Table 1) is used throughout Florida and 5 other states and was implemented by the ESTL in 1990. The following recommendations and soil-test interpretation ranges were coupled with grower-selected High, Medium, and Low N options (Table 1). The rates of $\mathrm{P}$ and $\mathrm{K}$ adopted at that time were modifications of still older rates. Changing $\mathrm{P}$ and $\mathrm{K}$ rates with increasing $\mathrm{N}$ use represented a consensus of the ad hoc Working Group, and was an attempt to balance field observations and limited research with a desire to insure adequate plant nutrition until additional research findings were available to confirm or refute these decisions.

\section{Fertilization Management Footnotes, 1990 to 1996}

The following footnotes were printed with all bahiagrass ESTL soil-test reports from 1990 to 1996.

Footnote 124: IFAS recommendations emphasize efficient fertilizer use without losses of yield or of crop quality. Efficient fertilizer use results in high production with minimum impact to our environment. Since fertilizer use and management are only two aspects of crop production, growers are encouraged to consider IFAS 
Table 1. Mehlich-1 (double acid) soil-test interpretations and Bahiagrass fertilization recommendations, 1990 to 1996

\begin{tabular}{|c|c|c|c|c|c|c|c|c|c|c|}
\hline \multirow[t]{3}{*}{ N Option } & \multicolumn{5}{|c|}{ Phosphorus Interpretation } & \multicolumn{5}{|c|}{ Potassium Interpretation } \\
\hline & Very Low & Low & Med. & High & $\begin{array}{l}\text { Very } \\
\text { High }\end{array}$ & $\begin{array}{l}\text { Very } \\
\text { Low }\end{array}$ & Low & Med. & High & Very High \\
\hline & \multicolumn{5}{|c|}{ pounds $\mathrm{P}_{2} \mathrm{O}_{5}$ /acre } & \multicolumn{5}{|c|}{ pounds $\mathrm{K}_{2} \mathrm{O} /$ acre } \\
\hline High & 40 & 40 & 0 & 0 & 0 & 80 & 80 & 40 & 0 & 0 \\
\hline Med. & 25 & 25 & 0 & 0 & 0 & 50 & 50 & 0 & 0 & 0 \\
\hline Low & 0 & 0 & 0 & 0 & 0 & 0 & 0 & 0 & 0 & 0 \\
\hline
\end{tabular}

recommendations in light of their entire management strategy, including financial considerations.

Footnote 131: Fertilization Management Notes for Bahiagrass Pastures

For new plantings, apply only $100 \mathrm{lb}$ N/A split as follows: apply $30 \mathrm{lb}$ N/A, all of the $\mathrm{P}_{2} \mathrm{O}_{5}$, and $50 \%$ of the $\mathrm{K}_{2} \mathrm{O}$ as soon as plants have emerged. Apply $70 \mathrm{lb}$ N/A and the remaining $\mathrm{K}_{2} \mathrm{O} 30$ to 50 days later.

For established stands of bahiagrass, apply all of the fertilizer in the early spring to maximize much-needed spring forage. Bahiagrass is a very efficient forager and recovers nutrients from deeper in the soil profile than other popular forage grasses so danger of leaching losses is low. Three fertilization options are presented below. Choose the option which most closely fits your fertilizer budget, management objectives, and land capability.

High-N Option Apply $160 \mathrm{lb}$ N/A and the soil-test-based recommended rates of $\mathrm{P}_{2} \mathrm{O}_{5}$ and $\mathrm{K}_{2} \mathrm{O}$ for each of your pastures. The fertilization rates suggested in this option are high enough to allow bahiagrass pasture to achieve well above average production. Management and environmental factors will determine how much of the potential production is achieved and how much of the forage is utilized.

Medium-Nitrogen Option Apply around 100 $\mathrm{lb}$ N/A this year. At that level of $\mathrm{N}$ fertilization, $\mathrm{P}$ and $\mathrm{K}$ may be limiting if your soil tested low in these nutrients. Apply $25 \mathrm{lb}$ $\mathrm{P}_{2} \mathrm{O}_{5} / \mathrm{A}$ if you soil tested low in $\mathrm{P}$ and none if it tested medium. Apply $50 \mathrm{lb} \mathrm{K}_{2} \mathrm{O} / \mathrm{A}$ if your soil tested low in $\mathrm{K}$ and none if it tested medium. Re-test you soil every second or third year to verify $\mathrm{P}$ and $\mathrm{K}$ levels. If you plan to make a late-season cutting of hay, apply $80 \mathrm{lb}$ N/A between August 1 and 15 (about 6 weeks before the growing season ends).

Low-Nitrogen Option (for Grazed Pastures Only) Apply around $50 \mathrm{lb}$ N/A this year, recognizing that $\mathrm{N}$ will be the limiting nutrient. Thus, do not apply $\mathrm{P}$ or K. If you follow this practice of applying only $\mathrm{N}$ to your pasture for more than one year, apply the $\mathrm{P}$ and $\mathrm{K}$ recommended by soil test every third or fourth year to avoid excessive depletion of those nutrients. Do not use this option if you cut hay since nutrient removal by hay is much greater than by grazing animals.

1996 Discussion and Recommendations from the Bahiagrass Fertilization Working Group

\section{Bahiagrass Fertilization Working Group Committee Members and Participants, 1994 to 1996}
E.A. Hanlon, Chair
F.M. Rhoads
F. Pate
C.G. Chambliss
G.H. Snyder
D. Townsend
J. Rechcigl
J.F. Selph
P. Mislevy
M.E. Griggs
R. Stanley
S.L. Sumner (retired)
D.L. Wright
J.B. Sartain
A.E. Kretschmer 


\section{Target Soil pH}

The Working Group expressed strong feelings concerning target $\mathrm{pH}$. Some members believed that Bahiagrass should be limed to 5.5, while others favored the 5.0 target $\mathrm{pH}$.

Replicated field trials (Rechcigl et al., 1993; Rechcigl et al., 1995) showed that addition of dolomitic lime increased Bahiagrass production up to a soil $\mathrm{pH}$ of 5.0. However, no yield increases were seen with calcitic limestone. This apparent disagreement could have been caused by a response to $\mathrm{Mg}$ from the dolomite. Two additional papers, both from north Florida (Teare et al., 1987; Blue, 1974), also reported no Bahiagrass yield response above a soil $\mathrm{pH}$ of 5.0 .

In a review of soil-test results from the ESTL, approximately $6 \%$ of the 1,400 soil samples for Bahiagrass production received by the ESTL per year (1994 through 1996) had a soil pH between 5.0 and 5.5. The response curves from research in central and south Florida were relatively flat from 4.7 through 5.3 .

The following compromise was approved. The state would be divided into NORTH and SOUTH designations. The NORTH and SOUTH designations (with a dividing line near Orlando, Figure 1) had already been used for turf recommendations for 15 years. Additionally, USDA-Natural Resources and Conservation Service classify soils above this line as Thermic and soils below this line as Hyperthermic. This approach allowed the liming recommendation to be changed for central and south Florida, matching the research findings from that area. The 1990 liming recommendations were kept for NORTH Florida.

The NORTH target $\mathrm{pH}$ was maintained at 5.5. The SOUTH target $\mathrm{pH}$ was set to 5.0. Additionally, footnote changes clarified the decision to lime (see the following Footnotes section).

\section{Liming and Fertilization Management Footnotes}

Footnote 803 was printed for any soil sample from the SOUTH zone with a lime requirement using a Target $\mathrm{pH}$ of 5.0.

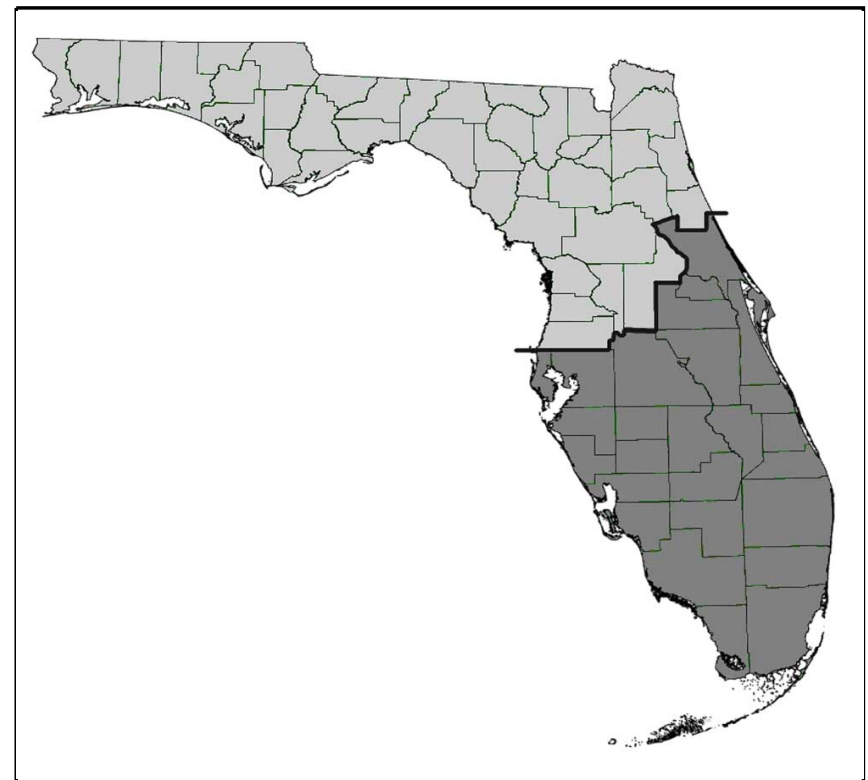

Figure 1. Map showing NORTH-SOUTH delineation used for recommendation purposes for successful Bahiagrass production in Florida.

Footnote 803: Lime soil with either dolomite or dolomitic limestone.

Footnote 810 was added to instruct growers about the relatively minimum need for lime for Bahiagrass pasture production.

Footnote 810: In central and south Florida, Bahiagrass pasture production has been modestly increased only with dolomitic limestone and only to a soil $\mathrm{pH}$ of 5.0. If your soil $\mathrm{pH}$ is between 4.8 and 5.3, you should base your need for lime on the economics of your production system.

\section{Fertilization Management: Phosphorus and Potassium}

Considerable discussion addressed whether or not soil testing assists with fertilizer management decisions for Bahiagrass. The literature in 1996 suggested:

1. That the Mehlich-1 (M-1) extractant values changed with additions of $\mathrm{P}$ or $\mathrm{K}$ to Bahiagrass pastures;

2. That the M-1 extractant was calibrated to yield responses from other improved grasses with the addition of fertilizers; and 
3. That the M-1 did not accurately predict

Bahiagrass response to $\mathrm{P}$ and $\mathrm{K}$ additions in some replicated and unreplicated field trials on Alfisols or Spodosols in central and south Florida. The reason for this inaccurate prediction is that Bahiagrass roots obtain $\mathrm{P}$ and $\mathrm{K}$ from soil horizons below the depth of soil sampling.

No soil testing calibrations for $\mathrm{P}$ and $\mathrm{K}$ fertilizer recommendations for Bahiagrass had been conducted on the Entisols and Ultisols in north Florida.

Traditionally, soil-test based recommendations have been used to improve production and/or quality of the immediate crop (Bahiagrass). In pasture situations, Bahiagrass is grown as a means for the production of cattle. Since cattle are the money-generating product, the profitability of cattle production actually controls the economics of Bahiagrass fertilization.

The responsibility for the economics of fertilization, while traditionally mentioned in management footnotes, has always been deferred to the grower. UF/IFAS can then avoid making general economic statements without knowing the specific economic conditions facing the rancher. The Working Group was divided on the issue of making Bahiagrass fertilization recommendations for the crop or the cattle. In the 1996 cattle market, Bahiagrass fertilization for pasture production was questionable, according to some knowledgeable Working Group members. At that time, there were no studies that fertilize Bahiagrass and then measure changes in beef production to resolve this dilemma.

In pasture situations, the Working Group also could not agree on the usefulness of soil testing for fertilizer management decisions. Most members agreed that for central and south Florida data, soil testing had done a poor job as a fertilizer management tool. However, these same members expressed doubts about the length of time that pastures would persist without additions of $\mathrm{P}$ and/or K. Soil testing every 3 years may provide a nutrient history for the surface soil, and may prove useful in detecting problems if a decline in plant persistence is noted. However, so long as there is a nutrient supply coming from the lower horizons, soil testing is unlikely to improve fertilizer management decisions.
Bahiagrass growth characteristics include the fact that its roots can actively grow in the Spodic (Bh) horizon (highly acidic soil, often containing elevated levels of Aluminum). To do so, bahiagrass must be tolerant of normally toxic levels of $\mathrm{Al}^{3+}$ found in Bh horizons in Florida. Work (Rechcigl et al., 1992) using tracers demonstrated that roots within the $\mathrm{Bh}$ horizon are active. Additional work showed that the $\mathrm{Bh}$ horizon is also considerably enriched in Mehlich-1 extractable $\mathrm{P}$, but that not all of this $\mathrm{P}$ is available for Bahiagrass uptake, since a large fraction exists in organic $\mathrm{P}$ forms. However, this additional $\mathrm{P}$ source was adequate to sustain Bahiagrass, permitting growth, but at somewhat deficient $\mathrm{P}$ plant-tissue concentrations.

Traditional soil testing for forages includes soil from the 0 - to 6-inch depth. The Bh horizon is often well below this sampling depth. Thus, traditional soil testing will not consider nutrients in the Bh horizon and could potentially over-predict the need for fertilization.

In the end, compromises were reached such that recommendations were based as much as possible on results from the literature. The recommendations from the Working Group included the following changes:

1. The Bahiagrass pasture $($ Crop code $=24)$ entry was expanded with the following statement:

"Bahiagrass pasture NOTE: In central and south Florida, recent field research has shown that soil testing is not a reliable tool for Bahiagrass pasture fertilizer management decisions, and is not recommended. Fertilizer decisions for Bahiagrass pastures should be based on the economics of your operations."

2. For soil samples originating from the NORTH zone:

a)Footnote 124 (see Bahiagrass Fertilization Recommendations Established in 1990) was used for Bahiagrass pasture soil samples. 
3. A new footnote, Footnote 132, based in part upon Footnote 124, was created for all Bahiagrass pasture soil samples from the SOUTH zone.

Footnote 132: IFAS recommendations emphasize efficient fertilizer use without losses of yield or of crop quality. Efficient fertilizer use results in high production with minimum impact to our environment. Since fertilizer use and management are only two aspects of crop production, growers are encouraged to consider IFAS recommendations in light of their entire management strategy, including financial considerations. In central and south Florida, soil-test based recommendations for Bahiagrass pasture fertilization should be evaluated on an economic basis using the rate of $\mathrm{N}$ fertilization, cattle productivity, and cattle prices.

4. The 1990 version of Footnote 131 was reworded to include Bahiagrass fertilization recommendations for both NORTH and SOUTH zones:

Footnote 131: Fertilization Management Notes for Bahiagrass Pastures:

For new plantings, apply only $100 \mathrm{lb}$ N/A split as follows: apply $30 \mathrm{lb}$ N/A, all of the $\mathrm{P}_{2} \mathrm{O}_{5}$, and $50 \%$ of the $\mathrm{K}_{2} \mathrm{O}$ as soon as plants have emerged. Apply $70 \mathrm{lb}$ N/A and the remaining $\mathrm{K}_{2} \mathrm{O} 30$ to 50 days later.

For Bahiagrass pastures in central and south Florida, recent research has shown that $\mathrm{P}$ and $\mathrm{K}$ fertilization may not be economical.

Furthermore, soil-test results may underestimate the soil supply of P. Choose to add $\mathrm{P}$ and $\mathrm{K}$ based upon economic considerations for your production system.

For established stands of bahiagrass, apply all of the fertilizer in the early spring to maximize much-needed spring forage. Bahiagrass is a very efficient forager and recovers nutrients from deeper in the soil profile than other popular forage grasses so danger of leaching losses is low. Three fertilization options are presented below. Choose the option which most closely fits your fertilizer budget, management objectives, and land capability.

High-N Option Apply $160 \mathrm{lb}$ N/A and the soil-test-based recommended rates of $\mathrm{P}_{2} \mathrm{O}_{5}$ and $\mathrm{K}_{2} \mathrm{O}$ for each of your pastures. The fertilization rates suggested in this option are high enough to allow bahiagrass pasture to achieve well above average production. Management and environmental factors will determine how much of the potential production is achieved and how much of the forage is utilized.

Medium-Nitrogen Option Apply around 100 lb N/A this year. At that level of $\mathrm{N}$ fertilization, $\mathrm{P}$ and $\mathrm{K}$ may be limiting if your soil tested low in these nutrients. Apply $25 \mathrm{lb}$ $\mathrm{P}_{2} \mathrm{O}_{5} / \mathrm{A}$ if your soil tested low in $\mathrm{P}$ and none if it tested medium. Apply $50 \mathrm{lb} \mathrm{K}_{2} \mathrm{O} / \mathrm{A}$ if your soil tested low in $\mathrm{K}$ and none if it tested medium. Re-test your soil every second or third year to verify $\mathrm{P}$ and $\mathrm{K}$ levels. If you plan to make a late-season cutting of hay, apply 80 lb N/A between August 1 and 15 (about 6 weeks before the growing season ends).

Low-Nitrogen Option (for Grazed Pastures Only) Apply around $50 \mathrm{lb}$ N/A this year, recognizing that $\mathrm{N}$ will be the limiting nutrient. Thus, do not apply P or K. If you follow this practice of applying only $\mathrm{N}$ to your pasture for more than one year, apply the $\mathrm{P}$ and $\mathrm{K}$ recommended by soil test every third or fourth year to avoid excessive depletion of those nutrients. Do not use this option if you cut hay since nutrient removal by hay is much greater than by grazing animals.

\section{Recommendation Changes made in 2003 sponsored by the Suwannee Fertilizer Work Group}

Using the approved recommendations in 1996 as a starting point, the Suwannee Fertilizer Work Group updated Bahiagrass recommendation in 2003 based upon new research findings. If new information was not available, then the content of the 
previously-approved footnotes was retained.

Wording, while primarily from the 1996-approved footnotes, was modified to emphasize topics that the Work Group felt was important. The following information indicates only those portions of the recommendations that were changed in 2003. Current management guidelines accompanying IFAS soil test reports have been described in EDIS Document SL 129 (Kidder et al., 2002). These footnotes address all types of management for Bahiagrass. Some footnotes also apply to other grasses as well.

Footnote 124: UF/IFAS fertilization and liming recommendations are advisory in nature and emphasize efficient fertilizer use and environmentally sound nutrient management without losses of yield or crop quality. It is generally assumed the nutrients will be supplied from purchased, commercial fertilizer and the expected crop yields and quality will be typical of economically viable production. Growers should consider IFAS recommendations in the context of their entire management strategy, such as return on investment in fertilizer and the benefits of applying manure or biosolids (sewage sludge) to their land.

There is insufficient research available to support the use of UF/IFAS soil test results for environmental nutrient management purposes. Such use is discouraged until correlation is proven.

Footnote 131: Fertilization Management Notes for Bahiagrass

Bahiagrass is probably the most widely-used improved forage grass in Florida. It responds well to grazing management and inputs such as fertilization. However, it also can persist and give satisfactory yields under little or no management. Bahiagrass is a very efficient forager and recovers nutrients from deeper in the soil than other popular forage grasses. Because of the wide range of possible use and management levels, recommendations for its fertilization differ with the level of management and the economic inputs. Management decisions concerning liming and fertilization of bahiagrass pastures are very sensitive to cattle productivity and prices.

Recent field research has shown no yield benefit to $\mathrm{P}$ or $\mathrm{K}$ fertilization of grazed bahiagrass pastures in central and south Florida, so soil testing for $\mathrm{P} \& \mathrm{~K}$ is not necessary in this part of the state. For purposes of this recommendation, central and south Florida is the region south of a line drawn approximately east-west through Orlando (Figure 1). If you are a producer from that region who has chosen to soil test and wish to follow the standardized recommendations for north Florida, those options are discussed below.

Establishment of New Plantings For new plantings, apply $80 \mathrm{lb}$ N/A split as follows: apply $30 \mathrm{lb} \mathrm{N} / \mathrm{A}$, all of the $\mathrm{P}_{2} \mathrm{O}_{5}$, and $50 \%$ of the $\mathrm{K}_{2} \mathrm{O}$ as soon as plants have emerged. Apply the remaining $\mathrm{K}_{2} \mathrm{O}$ and $50 \mathrm{lb}$ N/A 30 to 50 days later. If manure or biosolids are used as the main source of nutrients, apply the entire annual application once the plants are large enough to withstand physical damage from the application.

Maintenance Fertilization of Established Bahiagrass Pasture Four fertilization options are presented below for bahiagrass pastures. Choose the option which most closely fits your fertilizer budget, management objectives, and land capability.

If you will be only grazing your bahiagrass, you should carefully consider the potential for economical return on your investment in fertilizer before using the Medium-Nitrogen or High-Nitrogen options described below. The added forage produced for the grazing animals may not be worth the added cost.

Low-Nitrogen Option (for Grazed Pastures

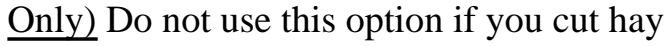
since nutrient removal by hay is much greater than by grazing animals. This option results in the lowest cost of purchased fertilizer. Apply around $50 \mathrm{lb}$ N/A in the early spring to maximize much-needed forage. Do not apply 
$\mathrm{P}$ or $\mathrm{K}$ recognizing that $\mathrm{N}$ will be the limiting nutrient in this low-cost option.

Medium-Nitrogen Option Apply $100 \mathrm{lb}$ N/A in the early spring to provide much-needed forage. At this level of $\mathrm{N}$ fertilization, $\mathrm{P}$ and $\mathrm{K}$ may be limiting if your soil tested low in these nutrients. Apply $25 \mathrm{lb} \mathrm{P}_{2} \mathrm{O}_{5} / \mathrm{A}$ if your soil tested very low or low in $\mathrm{P}$ and none if it tested medium or high. Apply $50 \mathrm{lb} \mathrm{K}_{2} \mathrm{O} / \mathrm{A}$ if your soil tested very low or low in $\mathrm{K}$ and none if it tested medium or high. Retest your soil every second or third year to verify $\mathrm{P}$ and $\mathrm{K}$ levels.

High-Nitrogen Option Apply $160 \mathrm{lb}$ N/A and the soil-test recommended rates of $\mathrm{P}_{2} \mathrm{O}_{5}$ and $\mathrm{K}_{2} \mathrm{O}$ for each of your pastures. Split the $\mathrm{N}$ into two applications of $80 \mathrm{lb}$ N/A each, applying in early spring and early summer. The fertilization rates suggested in this option are high enough to allow bahiagrass pasture to achieve well above average production. Management and environmental factors will determine how much of the potential production is achieved and how much of the forage is utilized. A single cutting of hay can be made without need for additional fertilization.

Fertilization of Pastures with Biosolids or Manure Apply no more than $160 \mathrm{lb}$ of total N/A per application and no more than $320 \mathrm{lb}$ of total N/A per year. (Note: In areas designated as phosphorus sensitive, the rate of application will be determined by other criteria).

Special Note if Applying Manure or Biosolids A different set of economic factors is usually considered when waste materials rather than purchased fertilizer are supplying the nutrients. Additionally, it is often impractical to follow the application timings discussed in this footnote when using waste materials from other operations.

$\underline{\text { Bahiagrass Cut Sometimes for Hay }}$
For a Single Cut Per Year from Pastures If you used the Low-N option of pasture fertilization, apply $80 \mathrm{lb}$ N/A and the soil-test recommended amount of $\mathrm{P}_{2} \mathrm{O}_{5}$ and $\mathrm{K}_{2} \mathrm{O}$ no later than six weeks before the growing season ends. If you used the Medium-N option of pasture fertilization, apply $80 \mathrm{lb} \mathrm{N}$ and $40 \mathrm{lb}$ $\mathrm{K}_{2} \mathrm{O} / \mathrm{A}$ no later than six weeks before the growing season ends. If you used the High-N option of pasture fertilization, you do not need any additional fertilization to make one cut of hay.

\section{Bahiagrass Grown Only for Hay}

For Multiple Cuts of Hay Apply $80 \mathrm{lb}$ N/A and the soil-test recommended rates of $\mathrm{P}_{2} \mathrm{O}_{5}$ and $\mathrm{K}_{2} \mathrm{O}$ in early spring. Apply an additional $80 \mathrm{lb}$ $\mathrm{N}$ and $40 \mathrm{lb} \mathrm{K}_{2} \mathrm{O} / \mathrm{A}$ after each cutting, except the last in the fall. Include $20 \mathrm{lb}$ of $\mathrm{P}_{2} \mathrm{O}_{5} / \mathrm{A}$ in the supplemental fertilizer if the soil tested low or medium in $\mathrm{P}$.

Bahiagrass for Seed Production Apply 60 to 80 $\mathrm{lb}$ N/A and the soil-test recommended P and K in February or March. Graze until May, June, or July, depending on variety. Remove cattle before seed heads start to emerge and apply an additional 60 to $80 \mathrm{lb}$ N/A.

If the bahiagrass is not grazed, do not apply fertilizer in February or March since this may stimulate excessive top growth. Mowing from February to April may be needed to remove excessive top growth. Apply the soil test recommended $\mathrm{P}$ and $\mathrm{K}$ and 60 to $80 \mathrm{lb}$ N/A before seed heads first appear. Fertilize Pensacola in March/April and Argentine and Paraguay in May/June.

\section{Footnote 132: HAY OR SILAGE (ALL PERENNIAL GRASSES)}

For Multiple Cuts Apply $80 \mathrm{lb}$ N/A and all of the recommended $\mathrm{P}_{2} \mathrm{O}_{5}$ and $\mathrm{K}_{2} \mathrm{O}$ in early spring. Apply an additional $80 \mathrm{lb} \mathrm{N}$ and $40 \mathrm{lb}$ $\mathrm{K}_{2} \mathrm{O} / \mathrm{A}$ after each cutting, except the last in the fall. Include $20 \mathrm{lb}$ of $\mathrm{P}_{2} \mathrm{O}_{5} / \mathrm{A}$ in the supplemental fertilizer if the soil tested low or medium in $\mathrm{P}$. 
For a Single, Late Season Cut from Pastures If you have not applied $\mathrm{N}$ in the past two months, apply $80 \mathrm{lb}$ N/A and the soil-test recommended amount of $\mathrm{P}_{2} \mathrm{O}_{5}$ and $\mathrm{K}_{2} \mathrm{O}$. If you have applied $\mathrm{N}$ in the past two months, do not apply any $\mathrm{N}$ now, but do apply the soil-test recommended amount of $\mathrm{P}_{2} \mathrm{O}_{5}$ and $\mathrm{K}_{2} \mathrm{O}$. Any application of fertilizer should be made no later than six weeks before the growing season ends.

Special Note if Applying Manure or Biosolids A different set of economic factors are usually considered when waste materials rather than purchased fertilizer are supplying the nutrients. Additionally, it is often impractical to follow the application timings discussed in this footnote when using waste materials from other operations.

\section{Summary}

The UF/IFAS recommendations for Bahiagrass have gone through several evolutionary steps from 1990 through 2003. These recommendations are founded in experimental evidence that has been published in a number of venues (see Bibliography section). Recommendations have changed considerably, affecting soil $\mathrm{pH}$ management, as well as appropriate phosphorus and potassium fertilization for hay, sod, and pasture management scenarios. High quality Bahiagrass production can be achieved in Florida if these recommendations are followed. Development of appropriate liming and fertilization recommendations is a continuing process. As the 2006 Forage Fertilization Working Group explores current issues involving Bahiagrass production, this document shall be updated to reflect these new findings.

\section{Bibliography}

1. Allen, R.J., Jr., and F.T. Boyd. 1959. Pasture development in the Everglades. Soil Crop Sci. Soc. Fla. Proc. 19:154-161.

2. Blue, W.G. 1966. The effect of nitrogen sources, rates and application frequencies on Pensacola bahiagrass forage yields and nitrogen utilization. Soil Crop Sci. Soc. Fla. Proc. 26:105-109.
3. Blue, W.G. 1970. The recovery of autumn and winter applied potassium by a warm-season grass from Leon fine sand. Soil Crop Sci. Soc. Fla. Proc. 31:75-77.

4. Blue, W.G. 1971. Nitrogen fertilization in relation to seasonal Pensacola bahiagrass (Paspalum notatum Flugge) forage nitrogen and production distribution on Leon fine sand. Soil Crop Sci. Soc. Fla. Proc. 30:9-15.

5. Blue, W.G. 1973. Role of Pensacola bahiagrass stolon-root systems in fertilizer nitrogen utilization on Leon fine sand. Agron. J 65:88-90.

6. Blue, W.G. 1988. Response of Pensacola bahiagrass on a Florida Spodosol to nitrogen sources and times of application. Soil Crop Sci. Soc. Fla. Proc. 47:135-139.

7. Blue, W.G. 1974. Efficiency of five nitrogen sources for Pensacola bahiagrass on Leon fine sand as affected by lime treatments. Soil Crop Soc. Fla. Proc. 33:176-180.

8. Blue, W.G. 1977. Comparison of sulfur-coated urea and ammonium nitrate as fertilizers for Pensacola bahiagrass on a Spodosol. Soil Sci. Soc. Am. J. 41:1191-1193.

9. Blue, W.G. 1979. Forage production and N contents, and soil changes during 25 years of continuous white clover: Pensacola growth on a Florida Spodosol. Agron. J. 71:795-798.

10. Blue, W.G. 1980. Soil fertility management for improved pastures. Soil Crop Sci. Soc. Fla. Proc. 39:5-8.

11. Blue, W.G. 1988. Response of Pensacola bahiagrass (Paspalum notatum Flugge) to fertilizer nitrogen on an Entisol and a Spodosol in north Florida. Soil Crop Sci. Soc. Fla. Proc. 24:20-26.

12. Blue, W.G., and N. Gammon, Jr. 1963. Differences in nutrient requirements of experimental pasture plots managed by grazing and clipping techniques. Soil Crop Sci. Soc. Fla. Proc. 23:152-161. 
13. Blue, W.G., C.L. Dantzman, and V. Impithuksa. 1980. The response of the three perennial warm-season grasses to fertilizer nitrogen on Eaugallie fine sand (Alfic Haplaquod) in Central Florida. Soil Crop Sci. Soc. Fla. Proc. 39:44-47.

14. Blue, W.G., D.W. Jones, and J.B. Sartain. 1976. Interpretation of soil and forage tissue analytical data. Memorandum.

15. Blue, W.G., N. Gammon, Jr., and H.W. Winsor. 1961. Accumulation of organic matter and nitrogen on flatwoods soils planted to white clover-grass pastures. Soil Crop Sci. Soc. Fla. Proc. 21:74-81.

16. Boyd, F.T. 1961. Fertility responses of St. Augustine, Pangola, and Pensacola bahia grasses on south Florida sandy soils. Soil Crop Sci. Soc. Fla. Proc. 19:172-178.

17. Carvalho, M.M., V. Freitas, A.B. Da Cruz Filho. 1994. Phosphorus requirements for the establishment of two forage grasses in an acid soil. Pesq. agropec. bras., Brasilia.

29(2):199-209.

18. Dantzman, C.L., J.E. McCaleb, and E.M. Hodges. 1967. Influence of fertilization rate and grass variety on extractable potassium and phosphorus in Flatwoods soils. Soil Crop Sci. Soc. Fla. Proc. 27:30-34.

19. Department of Agriculture and Consumer Services (DACS). 2005. Office of Agricultural Water Policy - Overview. 5E-1.023 Procedures for Landowners and Leaseholders to Submit a Notice of Intent to Implement Nitrogen Best Management Practices (BMPs). State of Florida, DACS, Tallahassee, FL. Available at: http://www.floridaagwaterpolicy.com/rules/ Rule_5E_1_023.html. Accessed: November 28, 2005.

20. Dunavin, L.S., Jr., and O.C. Ruelke. 1959. The evaluation of cold hardiness in Florida pasture grasses. Soil Crop Sci. Soc. Fla. Proc.

47:139-142.
21. Gammon, N., Jr., and W.G. Blue. 1961. Nitrogen in pasture and field crop production. Soil Crop Sci. Soc. Fla. Proc. 21:283-287.

22. Gonzalez, J.S., W.G. Blue, and C.L. Dantzman. 1973. Availability of native subsoil phosphorus in flatwoods soil from Central Florida. Soil Crop Sci. Soc. Fla. Proc. 32:138-141.

23. Hanlon, E.A. 1995. Current UF/IFAS recommendations regarding pasture fertilization. p.57-64 In W. Kunkle (ed.) 1995 Beef Cattle Shortcourse, Gainesville, FL.

24. Hodges, E.M, and J.E. McCaleb. 1959. Pasture development at the Range Cattle Station. Soil Crop Sci. Soc. Fla. Proc. 19:150-154.

25. Hodges, E.M., and F.G. Martin. 1975. Forage production of Perennial grasses as affected by fertilizer rate and season. Soil Crop Sci. Soc. Fla. Proc. 34:158-161.

26. Hodges, E.M., W.G. Kirk, F.M. Peacock and J.E. McCaleb. 1970. Supplemental feeding of steers on Pangolagrass and Pensacola bahiagrass warm season pastures (Series II). Soil Crop Sci. Soc. Fla. Proc. 30:337-341.

27. Ibrikci, H., E.A. Hanlon, and J.E. Rechcigl. 1992. Initial calibration and correlation of inorganic-phosphorus soil test methods with a bahiagrass field trial. Commun. Soil Sci. Plant Anal. 23(17-20):2569-2579.

28. Impithuksa, V., and W.G. Blue. 1977. The fate of fertilizer nitrogen applied to Pensacola bahiagrass on sandy soils as indicated by Nitrogen-15. Soil Crop Sci. Soc. Fla. Proc. 37:213-217.

29. Impithuksa, V., and W.G. Blue. 1985. Fertilizer nitrogen and nitrogen-15 in three warm-season grasses grown on a Florida Spodosol. Soil Sci. Soc. Am. J. 49:1201-1204.

30. Impithuksa, V., C.L. Dantzman, and W.G. Blue. 1979. Fertilizer nitrogen utilization by three warm-season grasses on an Alfic Haplaquod as indicated by nitrogen-15. Soil Crop Sci. Soc. Fla. Proc. 38:93-97. 
31. Impithuksa, V., W.G. Blue, and D.A. Graetz. 1984. Distribution of applied nitrogen in soil--Pensacola bahiagrass components as indicated by nitrogen-15. Soil Sci. Soc. Am. J. 48:1280-1284.

32. Jones, V. 1991. Set stocking recommended for spring pasture. The Stockman Grass Farmer. p. 8-9.

33. Kidder, G., S.L. Sumner, E.W. Jennings, and M. Ramsey. 1992. Save energy, resources, and money with IFAS bahiagrass pasture fertilization recommendations. Fla. Coop. Ext. Serv.

34. Kidder, G., C.G. Chambliss, and R. Mylavarapu. 2002. UF/IFAS Standardized Fertilization Recommendations for Agronomic Crops. SL129, Soil \& Water Science, Cooperative Extension Service, IFAS. p9.

35. Killinger, G.B. 1959. Pasture herbage changes in Florida during the past two decades (1939-1959). Soil Crop Sci. Soc. Fla. Proc. 19:162-165.

36. McCaleb, J.E., C.L. Dantzman, and E.M. Hodges. 1966. Response of panolagrass and Pensacola bahiagrass to different amounts of phosphorus and potassium. Soil Crop Sci. Soc. Fla. Proc. 26:248-256.

37. Monson, W.G., and G.W. Burton. 1984. Forage research at Tifton, Georgia. Soil Crop Sci. Soc. Fla. Proc. 43:1-2.

38. Monteiro, F.A., and W.G. Blue. 1990. Effects of sulfur and molybdenum applied to Spodosol on White Clover-Pensacola bahiagrass growth and composition. Soil Crop Sci. Soc. Fla. Proc. 49:72-77.

39. Mylavarapu, R.S. 2003. Role of an Extension Soil Testing Program in the Development of Best Management Practices: A Florida Case Study. Journal of Extension, 45(4) pp9.

40. Neller, J.R. 1963. Comparisons of phosphorus fertilizers for pastures on flatwoods soils in Florida. Soil Crop Sci. Soc. Fla. Proc. 4:55-60.
41. O'Donnell, J.J., J.E. Rechcigl, W.D. Pitman, and D.M. Sylvia 1991. Establishment and growth of Vigna parkeri on an acid Florida Spodosol in response to lime and phosphorus. p. 491-500. In R.J. Wright et al. (Eds.) Plant-soil interactions at low pH. Kluwer Academic Pub., Dordrecht, The Netherlands.

42. Pate, F.M. 1993. Mineral supplement is more important with new fertilizer recommendations. Florida Cattleman 57,11:32,50.

43. Phillips, J.M., and C.S. Snyder. 1988. Effect of limestone and magnesium on bahiagrass yield, quality, nutrient concentration and uptake and soil test levels. Arkansas Agr. Exp. Sta. Bull. 914, 23 p.

44. Rechcigl, J.E., G.G. Payne, A.B. Bottcher, and P.S. Porter. 1992. Reduced phosphorus application on bahiagrass and water quality. Agron. J. 84:463-468.

45. Rechcigl, J.E., P. Mislevy, and A.K. Alva. 1993. Influence of limestone and phosphogypsum on bahiagrass growth and development. Soil Sci. Soc. Am. J. 57:96-102.

46. Rechcigl, J.E., P. Mislevy, and F.M. Pate. 1991. Influence of limestone and phosphogypsum on bahiagrass growth and development. Ona A.R.E.C. Res. Rep. RC-1991-3:1-9.

47. Rechcigl, J.E., P. Mislevy, and H. Ibrikci. 1995. Response of established bahiagrass to broadcast lime and phosphorus. J. Prod. Agric. 8(2):249-253.

48. Rodriguez-Kabana, R., D.B. Weaver, R. Garcia, D.F. Robertson, and E.L. Carden 1989.

Bahiagrass for the management of root-knot and cyst nematodes in soybean. Nematropica. 19:185-193.

49. Rodulfo, S., and W.G. Blue. 1970. The availability to forage plants of accumulated phosphorus in Leon fine sand. Soil Crop Sci. Soc. Fla. Proc. 30:167-173. 
50. Ruelke, O.C. 1960. Fertility, as a limiting factor for pastures in Florida. Soil Crop Sci. Soc. Fla.

Proc. 20:23-27.

51. Ruelke, O.C., and G.M. Prine. 1971.

Performance of six hybrid Bermudagrasses, Pangola digitgrass, and Pensacola bahiagrass at three fertility levels in north central Florida. Soil Crop Sci. Soc. Fla. Proc. 31:67-71.

52. Saturnino, R., and W.G. Blue. 1967. The availability to forage plants of accumulated phosphorus in Leon fine sand. Soil Crop Sci. Soc. Fla. Proc. 30:167-173.

53. Schroder, V.N., and O.C. Ruelke. 1968.

Nutritional studies of root and shoot development of yellowed Bahiagrass. Soil Crop Sci. Soc. Fla. Proc. 28:35-43.

54. Snyder, G.H., and A.E. Kretschmer, Jr. 1988. A DRIS Analysis for Bahiagrass Pastures. Fla. Agric. Exp. Stn. Journal Series N. 8726.

55. Stanley, R.L., Jr., and R.W. Wallace. 1970. Crimson clover and Argentina bahiagrass yields as related to fertilizer rate and time of application. Soil Crop Sci. Soc. Fla. Proc. 30:90-99.

56. Sumner, S., W. Wade, J. Selph, J. Southwell, V. Hoge, P. Hogue, E. Jennings, P. Miller, and T. Seawright 1991. Fertilization of established Bahiagrass pasture in Florida. Univ. Fla., Fla. Coop. Extn. Serv. Circ. 916, Gainesville, FL.

57. Teare, I.D., D.L. Wright, R.L. Stanley, and B.T.

Kidd. 1986. The economics of fertilizing Bahiagrass under pines. Field Day handout.

58. Teare, I.D., D.L. Wright, R.L. Stanley, Jr., and B.T. Kidd. 1987. Bahiagrass response to lime and nitrogen under pines. Agron. J. 79:1-4.

59. Van Buren, N. 1991. Forage Fertility Management/Improving Quality Can Open New Customer Markets. Solutions p. 48-49, 58-59.

60. Weiser, G.C., and R.L. Smith. 1988. Nitrogen related characteristics of Switchgrass and Bahiagrass in Florida. Soil Crop Sci. Soc. Fla. Proc. 47:161-164. 